Check for updates

Cite this: RSC Adv., 2018, 8, 14347

\title{
Potent and selective inhibition of matrix metalloproteinases by lanthanide trichloride
}

\author{
Yanyan Wang, (D) ${ }^{a}$ Ye Wang, (DD ${ }^{b}$ Song An, ${ }^{b}$ Jinrui Zhang, ${ }^{b}$ Yuqian Han, ${ }^{a}$ Jinge $X u^{a}$ \\ Fang $\mathrm{Yu}^{\mathrm{a}}{ }^{\mathrm{a}}$ Dahai $\mathrm{Yu}^{\mathrm{b}}$ and Xuexun Fang ${ }^{\star \mathrm{b}}$
}

Matrix metalloproteinases (MMPs) are a family of $\mathrm{Zn}$-containing and $\mathrm{Ca}$-dependent proteases with vital roles in extracellular matrix remodeling. Deregulation of MMPs occurs in many pathological conditions such as cardiovascular diseases, inflammation, and cancer. The therapeutic potential of MMP inhibitors has been demonstrated in diseases such as arthritis and cancer. Here we demonstrated that the 3-valent lanthanide compounds $\mathrm{LaCl}_{3}, \mathrm{TbCl}_{3}, \mathrm{GdCl}_{3}, \mathrm{YbCl}_{3}$, and $\mathrm{EuCl}_{3}$ inhibit MMPs such as MMP-2, MMP-13, and MMP-14 (MT1-MMP). The inhibition is more potent and selective toward MT1-MMP compared to the other MMPs. $\mathrm{EuCl}_{3}$ was further selected to study the enzyme kinetics of the MT1-MMP inhibition. The results showed that the inhibition is a mixed type with anti-competition and non-competitive types, which indicated that inhibition was achieved by the compound bound to the non-active center of MT1MMP and changing the enzyme conformation. The interaction between $\mathrm{EuCl}_{3}$ and MT1-MMP was further studied by UV-visible (UV-vis) light absorption. $\mathrm{EuCl}_{3}$ caused a slight blue shift of the maximum absorption wavelength of MT1-MMP, indicating the interaction reduced protein hydrophobicity. Moreover, $\mathrm{EuCl}_{3}$ exerted substantial inhibitory effects on the migration of $\mathrm{HT}-1080$ cells. Thus, $\mathrm{EuCl}_{3}$ may play a role in modulating tumor cell behavior by inhibiting MMPs activities especially the MT1-MMP activity. These findings provide initial insight into the biological activity and potential therapeutic value of $\mathrm{EuCl}_{3}$.

Received 29th January 2018 Accepted 20th March 2018

DOI: $10.1039 / c 8 r a 00871 j$

rsc.li/rsc-advances
MT1-MMP inhibitors are organic compounds and antibody, and only few inorganic inhibitors have been reported. ${ }^{19-22}$ Our previous work on the effect of trivalent $\mathrm{Al}$ and Fe on MMPs revealed that these trivalent metal salts and their complexes all significantly affect the MMPs activity and the cell migratory and invasive capability. So we speculate that some other trivalent metal ions may also have the similar biological activity.

The 3-valent lanthanide compounds are all rare-earth elements that can generate trivalent compounds with similar chemical properties. Rare-earth metals are divided into two categories on the basis of electronic structure and chemical and physical properties as follows: light and heavy rare-earth metals. Given their antibacterial, antiviral, and antitumor activities, the 3-valent lanthanide compounds play an important role in disease-associated biological processes. ${ }^{23-27}$ The interaction of the europium ion $\left(\mathrm{Eu}^{3+}\right)$ with the protein $\alpha$-amylase, an important digestive enzyme in saliva and pancreatic juice, has been studied over wide ranges of $\mathrm{pH}$ and concentration. The protein provides three independent, noncooperative binding sites for $\mathrm{Eu}^{3+} .^{23}$ Reports indicated that the 3-valent lanthanide compounds affect tumor cell growth and MMP expression. ${ }^{22,24,25} \mathrm{~A}$ study found that $\mathrm{LaCl}_{3}$ exerts a concentration-dependent inhibitory effect on invasive tumor cells, and $\mathrm{LaCl}_{3}\left(<50 \mu \mathrm{mol} \mathrm{L}{ }^{-1}\right)$ inhibits the activity and expression of pro-MMP-2 but does not suppress the activated 
form of MMP-2. ${ }^{\mathbf{2 4}}$ The inhibitory activities of different valence metal compounds demonstrate that the lanthanide elements $\left(\mathrm{EuCl}_{3}, \mathrm{LaCl}_{3}\right.$, and $\left.\mathrm{PrCl}_{3}\right)$ can inhibit the protein activity of cdMMP-13. ${ }^{22}$ The antibacterial and antiviral activities of lanthanide element organic coordination compounds have also been investigated. ${ }^{25}$ We previously showed that trivalent aluminum salts and iron salts exert inhibitory effects on MMPs and hinder the tumor migration and metastasis without affecting cell viability ${ }^{26,27}$. However, the inhibitory effects of the 3-valent lanthanide compounds on MT1-MMP and the protein's related diseases have been rarely explored.

In this study, we aimed to test the effect of the 3-valent lanthanide compounds $\left(\mathrm{LaCl}_{3}, \mathrm{TbCl}_{3}, \mathrm{GdCl}_{3}, \mathrm{YbCl}_{3}\right.$, and $\left.\mathrm{EuCl}_{3}\right)$ on the activities of three MMPs. Then, the inhibition type of $\mathrm{EuCl}_{3}$ was further selected to study the enzyme kinetics of the MT1-MMP inhibition, because their inhibition is more potent and selective toward MT1-MMP compared to the other MMPs. Moreover conformational change of MT1-MMP and effect of $\mathrm{EuCl}_{3}$ on tumor cell behaviors at the cellular level were explored. This research is meaningful for understanding the role of trivalent metal complexes in regulating MMP activity.

\section{Experimental procedures}

\subsection{Materials and reagents}

The human fibrosarcoma carcinoma cell line HT-1080 were obtained from the ATCC (Rockville, MD). DQ-gelatin was purchased from Invitrogen. Gelatin was obtained from Sigma. The other reagents and solvents used in the experiments were of analytical or reagent grade, as deemed appropriate.

\subsection{Expression and purification of recombinant proteases}

The recombinant catalytic domains of human MMP-2, MMP-13, and MT1-MMP were expressed in Escherichia coli, purified, and refolded in our laboratory. ${ }^{28}$ After purification, the bioactivities of proteins and inhibition of MMP broad-spectrum inhibitors (Gm 6001) were examined using FLx800 fluorescence microplate reader. These recombinant proteases were applied for subsequent enzymatic experiments.

\subsection{Enzyme activity assay}

An FLx800 fluorescence microplate reader (Bio-Tek) was used to measure MMP activity. DQ-gelatin was employed as the substrate. Kinetic assays were conducted at $37{ }^{\circ} \mathrm{C}$ in $50 \mathrm{mM}$ HEPES buffer ( $\mathrm{pH}$ 7.5) containing $0.2 \mathrm{M} \mathrm{NaCl}, 1 \mathrm{mM}$ $\mathrm{CaCl}_{2}, 20 \mu \mathrm{M} \mathrm{ZnSO}$, and $0.05 \%$ Brij-35. For inhibition assays, the 3-valent lanthanide compounds were incubated with an appropriate quantity of MMPs for $45 \mathrm{~min}$ to ensure that equilibrium was reached before the fluorescent substrate was added. The inhibitory extent was determined using the initial rates with and without the inhibitor. The FLx800 fluorescence microplate reader (Bio-Tek) was also used to measure cathepsin activity, with z-Phe-Arg-AMC as the substrate. Other reagents are as follows: for cathepsin $\mathrm{K}$ : $50 \mathrm{mM}$ MEs, and $5 \mathrm{mM}$ DTT (pH 5.5); for cathepsin L: $0.4 \mathrm{M}$ NaOAc, $4 \mathrm{mM}$ EDTA, and $8 \mathrm{mM}$ DTT (pH 5.5). For enzyme inhibition assays, activity data were fitted into a linearized curve by using Origin version 7.5. $\mathrm{IC}_{50}$ values were then determined from the curve accordingly.

\subsection{Enzyme kinetics of $\mathrm{EuCl}_{3}$ on MT1-MMP}

To analyze inhibition type, we performed further kinetic analysis of the inhibition of the lanthanide metallic compound $\mathrm{EuCl}_{3}$ of MT1-MMP. We selected $1 \mu \mathrm{g} \mathrm{mL} \mathrm{m}^{-1}$ as the final enzyme concentration. The final inhibitor concentrations were selected as $0,0.2,0.4$, and $0.6 \mu \mathrm{M}$, respectively, in accordance with the detected $\mathrm{IC}_{50}=0.53 \mu \mathrm{M}$ during the inhibition of MT1-MMP by $\mathrm{EuCl}_{3}$. Substrates with different final concentrations $\left(0.5-7 \mu \mathrm{g} \mathrm{mL} \mathrm{m}^{-1}\right)$ were added. Inhibition type was identified using Lineweaver-Burk and Dixon plots. ${ }^{29,30}$

\section{$2.5 \quad$ UV-vis}

UV-vis absorption spectroscopy was conducted at $298 \mathrm{~K}$ on a UV2550 spectrophotometer equipped with $1.0 \mathrm{~cm}$ quartz cells. UV spectroscopy (200-500 nm wavelength) was recorded. Appropriate buffer solution running under the same conditions was considered as blank and subtracted from the sample spectra.

\subsection{Cell culture and measurement of cell viability (MTT)}

The human fibrosarcoma carcinoma cell line HT-1080 was cultured in Dulbecco's modified Eagle's medium (DMEM) containing $10 \%$ fetal bovine serum (FBS) supplemented with penicillin (100 units per $\mathrm{mL}$ ) and streptomycin $\left(100 \mu \mathrm{g} \mathrm{mL}{ }^{-1}\right)$ at $37^{\circ} \mathrm{C}$ and under $5 \% \mathrm{CO}_{2}$. HT1080 cells were seeded into 96-well plates at a density of $1 \times 10^{4}$ cells per well in $200 \mu \mathrm{L}$ of DMEM containing 10\% FBS. At $24 \mathrm{~h}$ after seeding, the medium was removed, and the cells were incubated for $24 \mathrm{~h}$ with DMEM containing $10 \%$ FBS in the absence or presence of various concentrations of metal complex. Subsequently, $200 \mu \mathrm{L}$ of DMEM and $20 \mu \mathrm{L}$ of $5 \mathrm{mg} \mathrm{mL} \mathrm{mTT}^{-1}$ (3-(4,5-dimethylthiazol-2-yl)-2,5diphenyltetrazolium bromide) solution was added to each well. The plates were placed in an incubator at $37^{\circ} \mathrm{C}$ in $5 \% \mathrm{CO}_{2}$ for $4 \mathrm{~h}$. Afterward, the medium was replaced with $150 \mu \mathrm{L}$ of DMSO, and absorbance was recorded at $490 \mathrm{~nm}$.

\subsection{Cell wound healing assay}

The migration rate was measured by wound healing assay. ${ }^{31} \mathrm{HT}$ 1080 cells were seeded into 24 -well plates at a density of $2 \times 10^{5}$ cells per well in $200 \mu \mathrm{L}$ of DMEM containing 10\% FBS. At $24 \mathrm{~h}$ after seeding, $200 \mu \mathrm{L}$ was used to create scratches of the same width at the bottom of the plate. The medium was removed, and the samples were washed with PBS and then photographed under a microscope. The cells were incubated for $24 \mathrm{~h}$ with DMEM containing $10 \%$ FBS in the absence or presence of various $\mathrm{EuCl}_{3}$ concentrations. The migrated cells were quantified on the basis of two photographic results. 


\section{Results and discussion}

\section{1 $\mathrm{EuCl}_{3}$ suppressed MT1-MMP activity in a dose- dependent manner}

Our previous work on the effect of trivalent $\mathrm{Al}$ and Fe on MMPs revealed that these trivalent metal salts and their complexes all significantly influence MMPs activity and the cell migratory and invasive capability. ${ }^{27}$ The significant inhibition of MMPs by these inorganic trivalent metal salts is a new discovery in the field of MMP inhibitors. Notably, lanthanide metallic compounds are trivalent compounds. MMP-2, MMP-13, and MT1-MMP belong to gelatinases, collagenases, and membrane MMPs, respectively. With different substrate degradation specificities, the enzymes can degrade various types collagen and gelatin, and participate in multiple physiological or pathological processes that require ECM remodeling. The excessive expression of these MMPs is closely associated with the migration, infiltration, and transfer of cancer cells. ${ }^{32-34}$

In the experiment, we selected several representative lanthanide compounds, namely, light rare-earth metallic compounds $\mathrm{LaCl}_{3}, \mathrm{GdCl}_{3}$, and $\mathrm{EuCl}_{3}$ and heavy rare earth metallic compounds $\mathrm{TbCl}_{3}$ and $\mathrm{YbCl}_{3}$, to analyze their effects on the activities of MMP-2, MMP-13, and MT1-MMP. Enzyme experiments demonstrated that with increasing concentration, the lanthanide compounds exert a significantly inhibited the MMP-2, MMP-13, and MT1-MMP activities, with $\mathrm{IC}_{50}$ values in the micromolar range (Table 1). The inhibition was selective toward MT1-MMP compared to other MMPs. Moreover, the suppressive effect $\left(\mathrm{IC}_{50}\right.$ of $\left.0.53 \mu \mathrm{M}\right)$ of $\mathrm{EuCl}_{3}$ on MT1-MMP was stronger than those of MMP-2 and MMP-13 (Table 1 and Fig. 1). Control experiments with fluorogenic substrate in the presence of lanthanide compounds alone was performed in the absence of the MMPs. Additionally, studies have shown that rare-earth metal ions had inhibitory activity to MMP-16 (MT3-MMP) with $\mathrm{IC}_{50} 3.5-14.5 \mu \mathrm{mol} \mathrm{L.} .^{35}$

To analyze whether lanthanide compounds can specifically inhibit MMPs, we selected cathepsin family members (cathepsin $\mathrm{K}$ and $\mathrm{L}$ ) with different catalytic mechanisms for enzyme activity analysis of the MMP family. Cathepsins are classified into the cysteine protease family, which contains a cysteine residue in the catalytic sites; this residue initiates proteolysis cascade reactions. Cathepsins play a key role in promoting the occurrence and development of tumors. cathepsin K and MMP-9 overexpression can promote the invasion and metastasis of gastric cancer cells. ${ }^{36}$ The proliferation and growth of tumor cells harboring the silenced cathepsin L gene are retarded, and the invasion is significantly reduced. ${ }^{37}$ Lanthanide compounds at a final concentration of $10 \mu \mathrm{M}$ exerted no inhibitory effect on the two cathepsins (Table 1). The inhibition of three recombinant proteases (MMP-2, MMP-13, and MT1-MMP) and cathepsins (cathepsin K and L) by lanthanide compounds were compared. Results showed that the lanthanide compounds successfully inhibited the three MMPs, with relative specificity for MT1-MMP.

\subsection{Inhibition types of $\mathrm{EuCl}_{3}$ on MT1-MMP}

Because inhibition of lanthanide compounds is more potent and selective toward MT1-MMP compared to the other MMPs, and the suppressive effect of $\mathrm{EuCl}_{3}$ on MT1-MMP was stronger than lanthanide compounds, we conducted further dynamic analysis on the inhibition of MT1-MMP by $\mathrm{EuCl}_{3}$. Different enzyme concentrations were added to the test system, and the same amounts of substrate and inhibitor were added. In the experiments, $1 \mu \mathrm{g} \mathrm{mL}^{-1}$ was selected as the final enzyme concentration for analyzing the inhibitory type. The corresponding final inhibitor concentrations were $0,0.2,0.4$, and 0.6 $\mu \mathrm{M}$, which were based on the detected $\mathrm{IC}_{50}=0.53 \mu \mathrm{M}$ during the $\mathrm{EuCl}_{3}$-mediated inhibition of MT1-MMP, and substrates at different final concentrations $\left(0.5-7 \mu \mathrm{g} \mathrm{mL} \mathrm{mL}^{-1}\right)$ were added. Fig. 2A and B display the plots on the Michaelis-Menten and Lineweaver-Burk equations, respectively. With increasing inhibitor concentration from $0 \mu \mathrm{M}$ to $0.2 \mu \mathrm{M}, K_{\mathrm{m}}$ and $V_{\max }$ obviously diminished. With further increase from $0.2 \mu \mathrm{M}$ to 0.6 $\mu \mathrm{M}, K_{\mathrm{m}}$ became constant, whereas $V_{\max }$ decreased. Therefore, the observed inhibition was a combination of non-competition and anti-competition. Meanwhile, the Dixon equation plots were used to obtain Fig. 2C. The two straight lines (substrate concentrations of 3 and $4 \mu \mathrm{g} \mathrm{mL} \mathrm{m}^{-1}$ ) intersected at the second quadrant with the intersection point as $-K_{\mathrm{i}}$. The results suggest that the inhibition is a combination of non-competition and anti-competition inhibition, that is, the inhibitor combined the compounds with the non-active center of MMP and altered the structure and conformation of MMP. This discovery has not been reported.

Table $1 \quad \mathrm{IC}_{50}$ of lanthanide compounds on MMPs (MMP-2, MMP-13, and MT1-MMP) and cathepsins (cathepsin K and L) ${ }^{a}$



$a$ "NI" means no inhibition was observed for the activity of the corresponding enzyme under $10 \mu \mathrm{M}$ lanthanide metallic compounds. The standard deviation value represent standard errors from three replicates. 
A

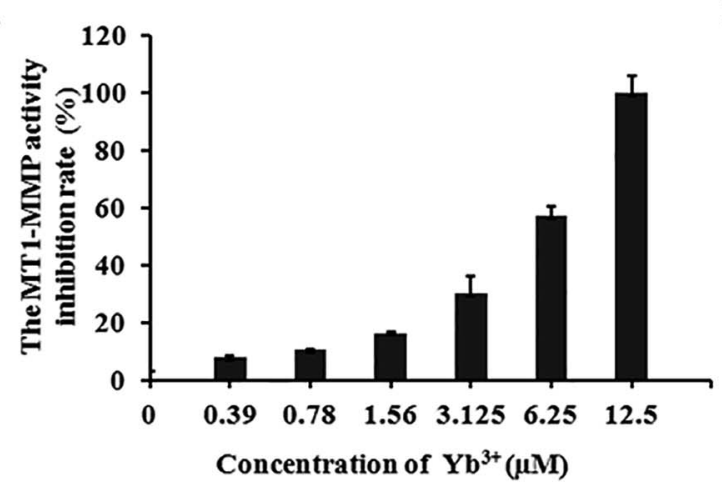

C

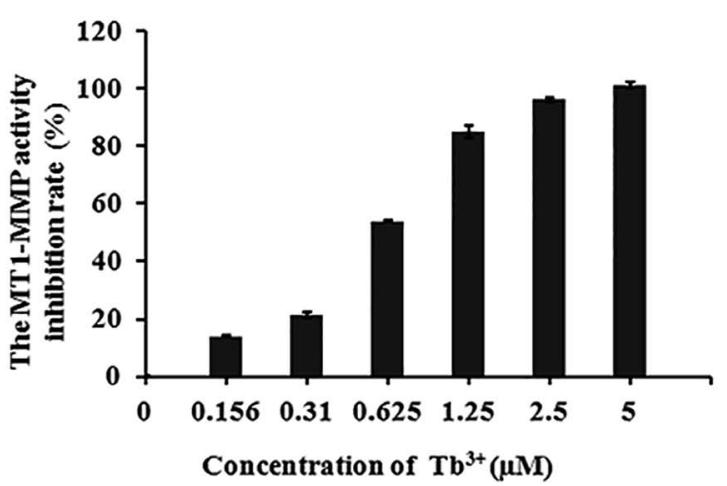

$\mathrm{E}$

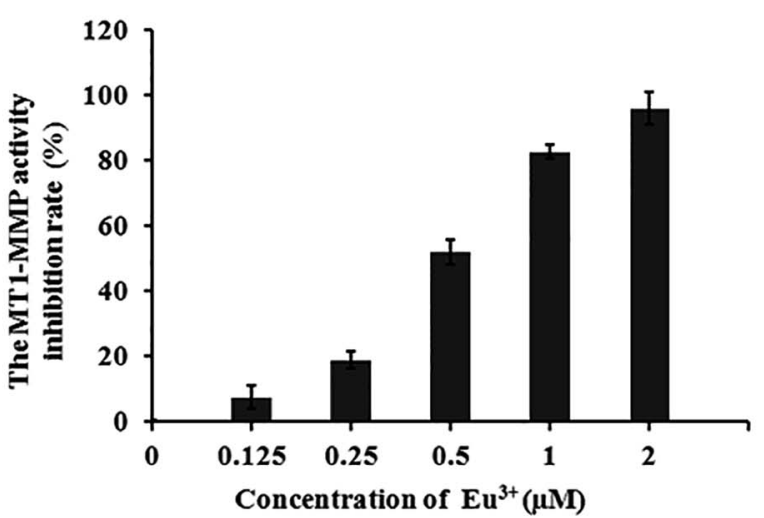

B

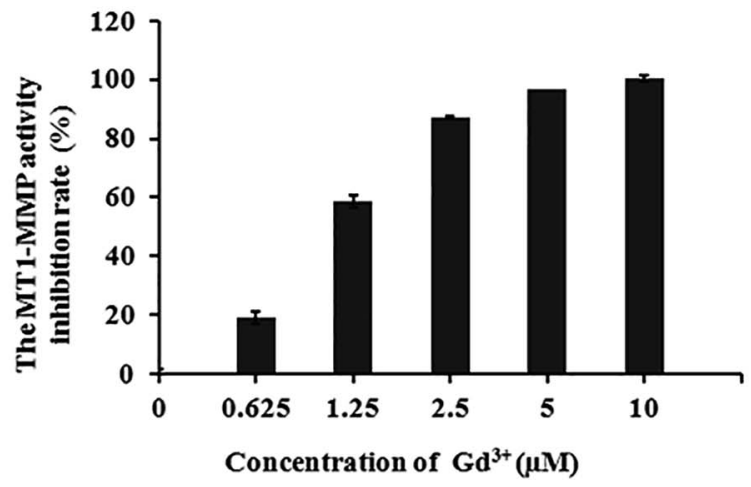

D



F

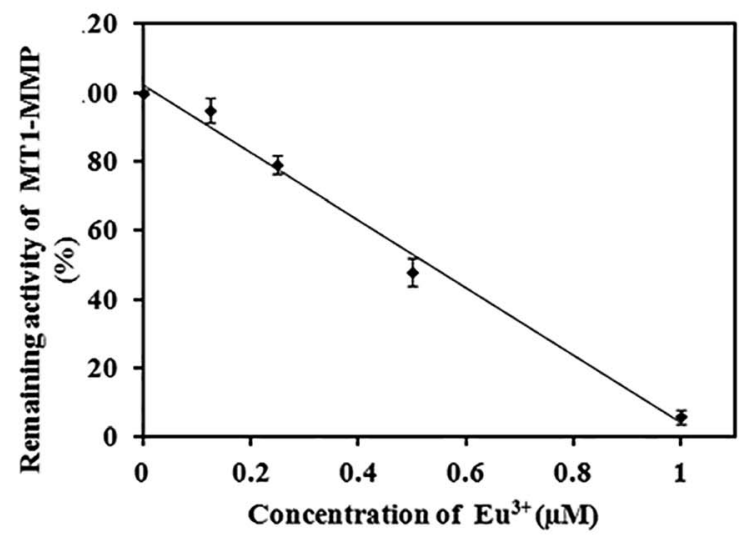

Fig. 1 Dose-dependent inhibition effect of the lanthanide metallic compounds on MT1-MMP. (A-E): MT1-MMP activity inhibition rate; (F) IC 50 of $\mathrm{Eu}^{3+}$ on MT1-MMP. the $\mathrm{IC}_{50}$ values were then determined from the curve accordingly. Data are presented as the mean values $(n=3)$. The activity data were fitted in a linearised curve using origin version 7.5. The $\mathrm{IC}_{50}$ values were then determined from the curve accordingly.

\section{3 $\mathrm{EuCl}_{3}$ effect on conformation by interaction with MT1-} MMP

UV-vis absorption is commonly used to study the secondary structural alterations in proteins. We obtained the UV-vis absorption spectra of MT1-MMP in different $\mathrm{EuCl}_{3}$ concentrations. Absorptions were significantly enhanced as $\mathrm{EuCl}_{3}$ concentration increased. The hyperchromic effect and blue shift of the absorption spectrum showed an increased binding of $\mathrm{EuCl}_{3}$ and MT1-MMP and decreased hydrophobicity for lightemitting residues (Fig. 3). The effects of other lanthanides were not evident.

MT1-MMP is synthesized with a signal peptide (Signal), a prodomian (Pro) for latency, a catalytic domain (Catalytic) with catalytic zinc atom ( $\mathrm{Zn}$ ) for proteolytic activity, a linker-1 (L1), a hemopexin domain (Hpx), a linker-2 (L2), a transmembrane domain (TM), and a cytoplasmic tail (CP). There is an RRKR motif at the border between the pro and catalytic domains which is recognized and cleaved by proprotein convertases (PCs) for activation. ${ }^{38}$ The catalytic $\mathrm{Zn}^{2+}$ ion is located near the protein surface, with the cleft above the metal site allowing binding of substrate peptides. In its resting state the $\mathrm{Zn}$ ion is coordinated by three His residues (His239, His243, His249 for MT1-MMP) and at least one water molecule which serves as the nucleophile during substrate hydrolysis. ${ }^{39,40}$ The pocket in the core domain is hydrophobic in nature, but variable in depth depending on the MMPs, representing a determining factor of substrate specificity of MMPs. The depth and 
A

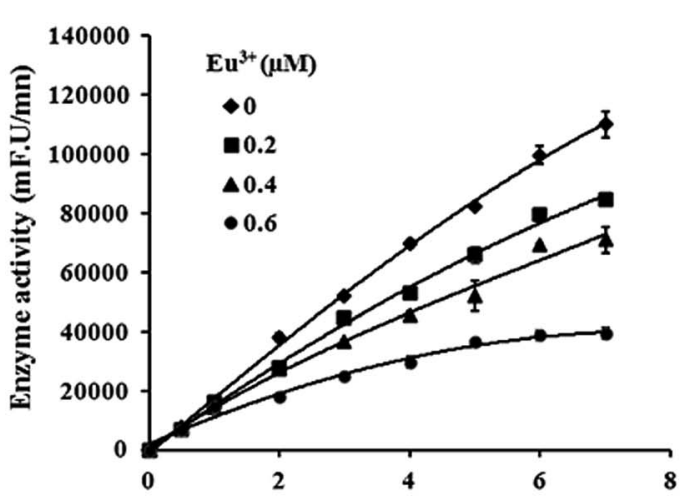

Substrate concentration $(\mu \mathrm{g} / \mathrm{mL})$

B

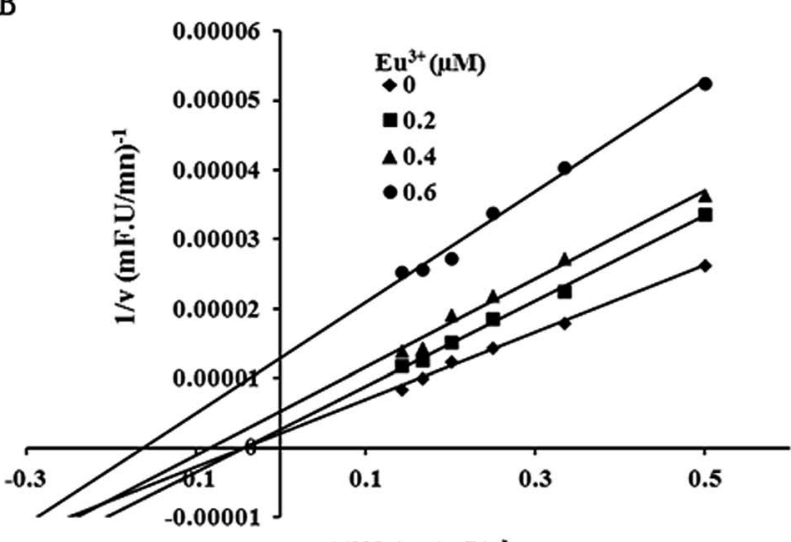

$1 /[\mathrm{S}](\mu \mathrm{g} / \mathrm{mL})^{-1}$

C

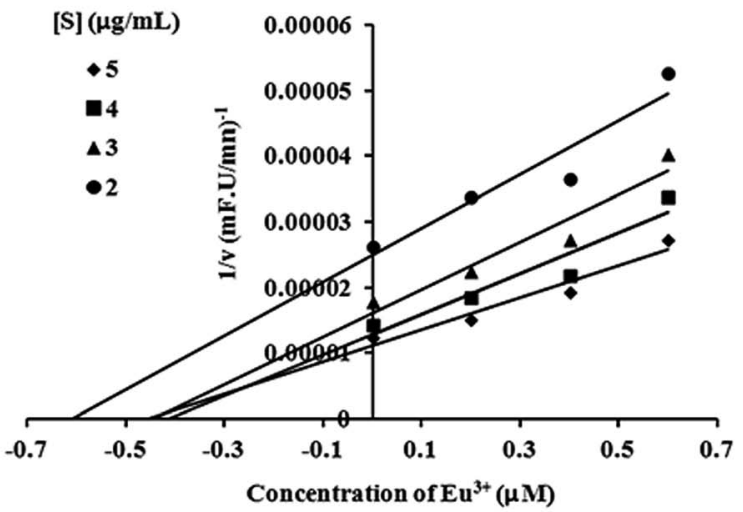

Fig. 2 Mixed-type inhibition kinetics of $\mathrm{EuCl}_{3}$ on MT1-MMP activity. (A) MT-MMP activity in the presence of different $\mathrm{EuCl}_{3}$ and substrate concentrations. (B) Lineweaver-Burk plot; $\mathrm{EuCl}_{3}$ concentrations were 0 (closed diamond), 0.2 (closed squares), 0.4 (closed triangles), and 0.6 $\mu \mathrm{m}$ (closed circles). (C) Dixon plots of the reversible enzyme inhibitors. The substrate concentrations for curves $1-4$ were 2, 3, 4, and 5 $\mu \mathrm{g} \mathrm{mL^{-1 }}$, respectively.

the length of the $\mathrm{S1}^{\prime}$ pocket and amino acids all represent critical foundations for the design and synthesis of matrix metalloproteinase inhibitors (MMPIs). ${ }^{41}$

They often have carboxylate or amide functions which provide strong interactions with the lanthanide cation, but differ in the structure of the molecular edifice. The different

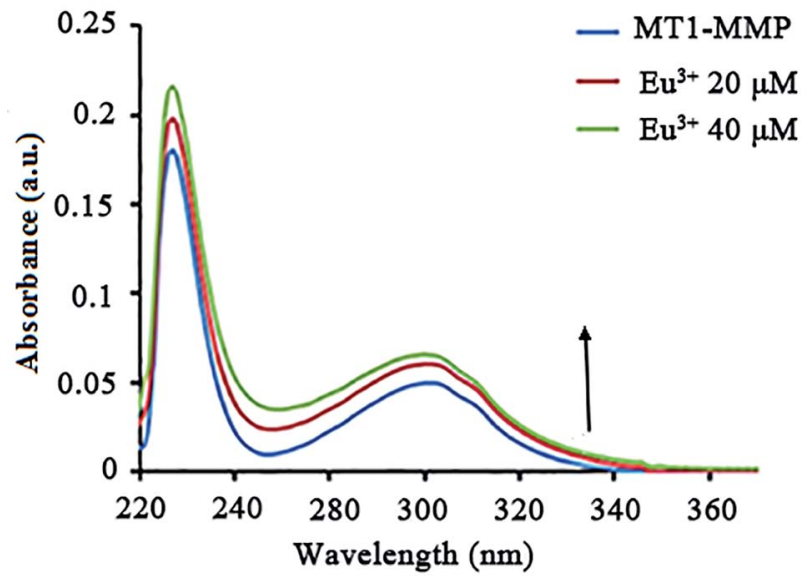

Fig. 3 UV-vis absorption spectra of MT1-MMP in the presence of $\mathrm{EuCl}_{3}$ the MT1-MMP concentration was $10-5 \mathrm{~mol} \mathrm{~L}^{-1}$ in $50 \mathrm{~mm}$ HEPES buffer (ph 7.5) containing $0.2 \mathrm{~m} \mathrm{NaCl}, 1 \mathrm{~mm} \mathrm{CaCl}, 20 \mu \mathrm{m} \mathrm{ZnSO}_{4}$, and $0.05 \%$ Brij-35. Measurement was conducted at $298 \mathrm{~K}$.

strategies developed up to now may be divided into four categories: (i) easy to reach acyclic structures incorporating a heteroaromatic (poly) cycle fitted with chelating groups based on the EDTA, DTPA or TTHA scaffold, (ii) podand-type receptors where anionic functionalized heteroaromatic moieties are attached to a single atom (nitrogen, carbon) or a small aromatic ring such as benzene, (iii) predisposed macrocyclic structures bearing coordinating and sensitizing units, (iv) more elaborate structures such as rigid cryptand-like macrobicyclic architectures14 or ligands based on self-assembly processes. ${ }^{42}$ Other researches have reported that $\mathrm{Eu}^{3+}$ has coordination role with oxygen and N, similar to iron ions. Moreover, the report points out: $\mathrm{Fe}^{3+}$ has been described as interacting with 3 His residues
A

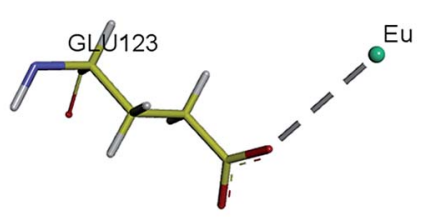

C

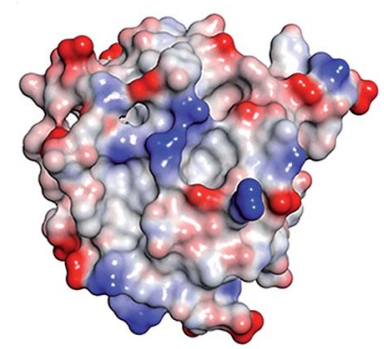

B

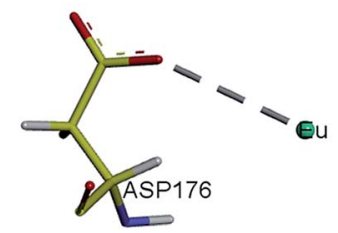

$\mathrm{D}$

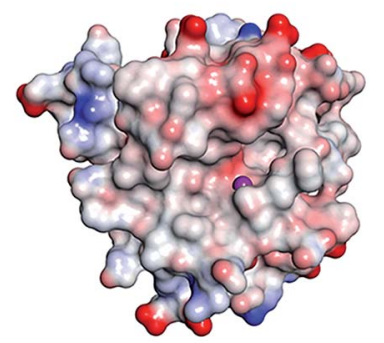

Fig. 4 Predicted binding mode of $\mathrm{EuCl}_{3}$ with MT1-MMP. (A and B) Molecular docking of $\mathrm{Eu}^{3+}$ and negatively charged amino acids in MT1MMP. ( $C$ and D) Charge distribution on the MT1-MMP surface. The red part is the negative charge, and the blue part is the positive charge. Deeper color indicates a stronger trend. 
A

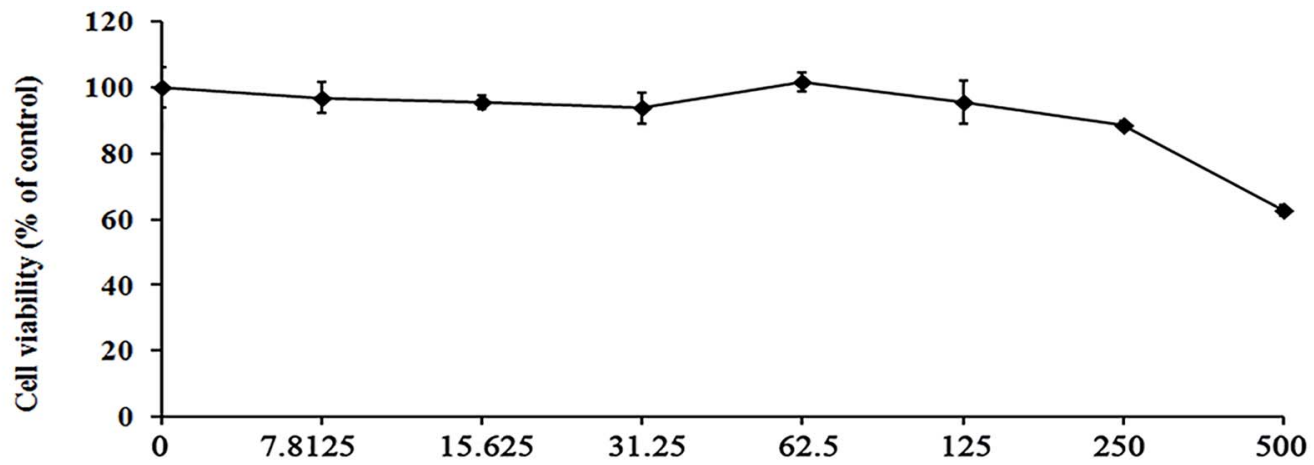

B

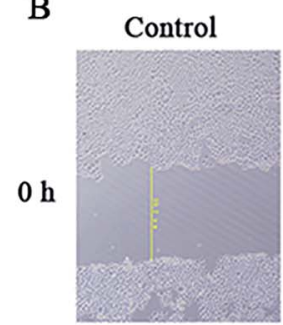

$24 \mathrm{~h}$

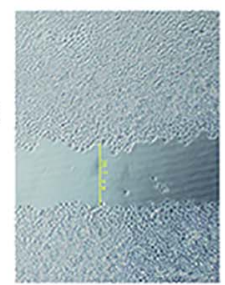

$25 \mu \mathrm{M} \mathrm{Eu}^{3+}$
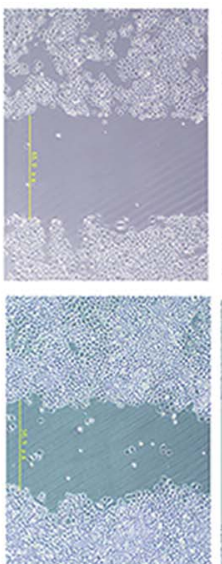

Concentration of $\mathrm{Eu}^{3+}\left(10^{-6} \mathrm{M}\right)$

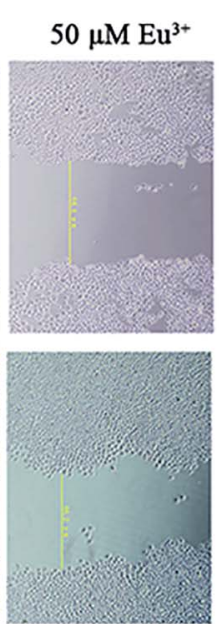

$\mathrm{C}$



Fig. $5 \mathrm{Eu}^{3+}$-inhibits HT-1080 cell migration in a dose-dependent manner without affecting cell viability. (A) An in vitro study was initiated by treating $\mathrm{HT}-1080$ cells with increasing doses of $\mathrm{Eu}^{3+}(0,7.8125,15.625,31.25,62.5,125,250$, and $500 \mu \mathrm{m})$ for $24 \mathrm{~h}$. The viability of the Eu ${ }^{3+}$ treated cells was measured using MTT assay. Results are expressed as percentages of control experiments. (B) Approximately $1 \times 105$ cells were seeded into 24-well plates with cell culture inserts. At $24 \mathrm{~h}$ after seeding, $200 \mu \mathrm{L}$ was used to create scratches with uniform width at the bottom of the plate. The medium was removed, samples were washed with PBS, and cells were photographed under microscope. Cells were subsequently incubated for $24 \mathrm{~h}$ with DMEM containing $10 \% \mathrm{FBS}$ in the absence or presence of various concentrations of EuCl $3(0,25$, and $50 \mu \mathrm{m})$. After $24 \mathrm{~h}$ of incubation, cell migration was visualized under a microscope. (C) Cell migration ratio was calculated from the average total number of cells of three filters. Results are presented as the mean $\pm \mathrm{sd}$ of three independent experiments. * indicates $p<0.05$ compared with the controls. ** indicates $p<0.01$ compared with the controls. Data are shown as mean \pm sd from three independent experiments.

in $\mathrm{Zn}$ binding site of MMPs. However, enzyme kinetics result showed that $\mathrm{Eu}^{3+}$ interacts with the inactive regions of MT1MMP.

Research has shown that positively charged metal ion can interact with negatively charged amino acids. ${ }^{43}$ On the basis of enzymology experiments, we selected the negatively charged amino acids Glu and Asp around the active pocket of MT1-MMP and performed molecular docking. Results revealed that these two amino acids induced metal complexation with $\mathrm{Eu}^{3+}$ (Fig. 4A and B). Docking energy analysis results indicated strong interaction between $\mathrm{Eu}^{3+}$ and Asp. Findings on enzyme kinetics showed that $\mathrm{Eu}^{3+}$ can interact with the inactive regions of MT1MMP at low concentrations; such interaction resulted in protein conformational changes. Then, the inhibitory mechanism shifted to anti-competitive mode with increased inhibitor concentration. Given the above results, we speculated that $\mathrm{Eu}^{3+}$ interacted with the negatively charged areas on the MT1-MMP surface at low concentrations. However, the red areas were gradually saturated by $\mathrm{Eu}^{3+}$ with increasing inhibitor concentration. $\mathrm{Eu}^{3+}$ interacted with the light-red region near the active center of the zinc ions of MT1-MMP (areas of interaction between enzyme and substrate) (Fig. 4C and D). The interaction sites site between areas should be verified by further study.

\section{4 $\mathrm{EuCl}_{3}$ can effectively inhibit the migration behaviors of HT-1080 cells without affecting cell vitality}

On the basis of the specific inhibitory effects on MT1-MMP, we examined the influences of $\mathrm{EuCl}_{3}$ on the behaviors of MT1MMP-related tumor cells. MTT assay was applied to determine the toxicity of $\mathrm{EuCl}_{3}$ on HT-1080 cells. Results revealed that $\mathrm{EuCl}_{3}$ was not found cytotoxic above a concentration of $250 \mu \mathrm{M}$ (Fig. 5A). However, cell viability suddenly decreased at concentrations exceeding $250 \mu \mathrm{M}$. This trend may be attributed to the sharp increase in cell permeability when chloroauric acid entered the cells; this occurrence eventually led to cell death 
and decreased cell viability. On the basis of the aforementioned results, $0-50 \mu \mathrm{M}$ was selected as the drug concentration range in the subsequent cell experiments on the influence of the metallic compounds on tumor cell behavior without affecting cell vitality.

Migration rate was measured by cell wound healing assay. Wound healing assay is simple, inexpensive, and among the earliest developed methods for investigating directional cell migration in vitro. This method mimics cell migration during wound healing in vivo. The basic steps include creating a "wound" in a cell monolayer, capturing the images at the beginning and at regular intervals during cell migration to close the wound, and comparing the images to quantify the migration rate of the cells. This method is particularly suitable for studies on the effects of cell matrix by secreting hydrolytic enzymes, such as MMPs and cell-cell interactions on cell migration. ${ }^{44}$ As shown in Fig. 5B and C, the migration rate was decreased significantly with increasing lanthanide metallic compound concentration. When the final $\mathrm{EuCl}_{3}$ concentration was $25 \mu \mathrm{M}$, the migration rate was $<50 \%$ relative to that of the control. When the final $\mathrm{EuCl}_{3}$ concentration was $50 \mu \mathrm{M}$, the migration rate declined to approximately $30 \%$. Therefore, the aforementioned results show that $\mathrm{EuCl}_{3}$ exerts obvious concentration-dependent inhibitory effects on HT-1080 cell migration.

\section{Conclusion}

In this work, we found that lanthanide metallic compounds of $\mathrm{Eu}^{3+}$ can inhibit MT1-MMP activity. According to dynamic analysis results, inhibition was achieved by combining the compounds with the non-active center of MT1-MMP and changing the structure and conformation of the enzyme. UV-vis absorption results showed that $\mathrm{EuCl}_{3}$ caused a slight blue shift of the maximum absorption wavelength of MT1-MMP, denoting the decrease in hydrophobicity of the protein. The role of $\mathrm{Eu}^{3+}$ and amino acids were analyzed. These results showed that $\mathrm{EuCl}_{3}$ interacted with the recombinant MT1-MMP and inhibited MT1-MMP activity. Moreover, at $0-50 \mu \mathrm{M} \mathrm{EuCl}{ }_{3}$ exerted significant inhibitory effects on cell migration but did not affect the cell viability of the human fibrosarcoma cells HT-1080. This research is highly meaningful for understanding the role of trivalent metal complexes in regulating MMP activity. However, questions regarding the exact MT1-MMP and $\mathrm{Eu}^{3+}$ sites, the nature of the $\mathrm{Eu}^{3+}$-induced MT1-MMP conformational change that reduced the activity level of the enzyme, and whether $\mathrm{Eu}^{3+}$ binding causes any dysfunction in MT1-MMP in vivo remain to be determined. These issues entail further detailed study on the interaction between MT1-MMP and $\mathrm{Eu}^{3+}$ and signal transduction pathways.

\section{Conflicts of interest}

There are no conflicts to declare.

\section{Acknowledgements}

The authors gratefully acknowledge the financial support from the National Natural Science Foundation of China (no. 31100574 and 31370742) and from the Department of Education of Liaoning Province (no. 2016J048).

\section{References}

1 P. Bischof and A. Campana, Baillière's Clinical Obstetrics and Gynaecology, 2000, 14, 801-814.

2 V. Srinivasan, D. W. Spence, A. Moscovitch, S. R. PandiPerumal, I. Trakht, G. M. Brown and C. D. P. Cardinali, J. Pineal Res., 2010, 48, 1-8.

3 K. Ganguly, A. V. Sharma, R. J. Reiter and S. Swarnakar, J. Pineal Res., 2010, 49, 130-140.

4 M. D. Sternlicht and Z. Werb, Annu. Rev. Cell Dev. Biol., 2001, 17463-17516.

5 M. Ege blad and Z. Werb, Nat. Rev. Cancer, 2002, 2, 161-174. 6 J. F. Dilmé, S. Bellmunt, M. Camacho, D. Solà-Villà, J. M. Romero, J. R. Escudero and L. Vila, Eur. J. Vasc. Endovasc. Surg., 2014, 48, 374-381.

7 J. M. Milner and T. E. Cawston, Curr. Drug Targets Inflamm. Allergy, 2005, 4, 363-375.

8 P. S. Burrage and C. E. Brinckerhoff, Curr. Drug Targets, 2007, 8, 293-303.

9 G. Murphy and H. Nagase, Nat. Rev. Rheumatol., 2008, 4, 128135.

10 E. Kerkelä and U. Saarialho-Kere, Exp. Dermatol., 2003, 12, 109-125.

11 C. Amălinei, I. D. Căruntu and R. A. Bălan, Rom. J. Morphol. Embryol., 2007, 48, 323-334.

12 H. Sato, T. Takino, Y. Okada, J. Cao, A. Shinagawa, E. Yamamoto and M. Seiki, Nature, 1994, 370, 61-65.

13 W. Zhang, L. M. Matrisian, K. Holmbeck, C. C. Vick and E. L. Rosenthal, BMC Cancer, 2006, 6, 52.

14 T. H. Chun, F. Sabeh, I. Ota, H. Murphy, K. T. McDonagh, K. Holmbeck, H. Birkedal-Hansen, E. D. Allen and S. J. Weiss, J. Cell Biol., 2004, 167, 757-767.

15 T. Sakamoto and M. Seiki, Genes Cells, 2009, 14, 617-626.

16 F. Sabeh, D. Fox and S. J. Weiss, J. Immunol., 2010, 184, 63966406.

17 M. C. Miller, H. B. Manning, A. Jain, L. Troeberg, J. Dudhia, D. Essex, A. Sandison, M. Seiki, J. Nanchahal, H. Nagase and Y. Itoh, Arthritis Rheum., 2009, 60, 686-697.

18 M. Seiki, Cancer Lett, 2003, 194, 1-11.

19 L. Devy, L. Huang, L. Naa, N. Yanamandra, H. Pieters, N. Frans, E. Chang, Q. Tao, M. Vanhove, A. Lejeune, R. van Gool, D. J. Sexton, G. Kuang, D. Rank, S. Hogan, C. Pazmany, Y. L. Ma, S. Schoonbroodt, A. E. Nixon, R. C. Ladner, R. Hoet, P. Henderikx, C. Tenhoor, S. A. Rabbani, M. L. Valentino, C. R. Wood and D. T. Dransfield, Cancer Res., 2009, 69, 1517-1526.

20 A. M. Woskowicz, S. A. Weaver, Y. Shitomi, N. Ito and Y. Itoh, J. Biol. Chem., 2013, 288, 35126-35137.

21 A. K. Chaudhary, S. Pandya, K. Ghosh and A. Nadkarni, Mutat. Res., 2013, 753, 7-23. 
22 H. Wen, Y. Qin, W. Zhong, C. Li, X. Liu and Y. Shen, Enzyme Microb. Technol., 2016, 92, 9-17.

23 A. Barkleit, A. Heller, A. Ikeda-Ohno and G. Bernhard, Dalton Trans., 2016, 45, 8724-8733.

24 M. Valko, H. Morris and M. T. Cronin, Curr. Med. Chem., 2005, 12, 1161-1208.

25 C. Shiju, D. Arish and S. Kumaresan, Spectrochim. Acta, Part A, 2013, 105, 532-538.

26 Y. Wang, H. Lu, D. Yu, J. Zhang, W. Liang, Z. Zhang and $\mathrm{X}$. Fang, RSC Adv., 2015, 5, 17700-17708.

27 Y. Shen, S. Liu, F. Jin, T. Mu, C. Li, K. Jiang, W. Tian, D. Yu, Y. Zhang and X. Fang, BioMetals, 2012, 25, 541-551.

28 X. Shi, F. Jin, H. Wang, J. Yang, Z. Wang and X. Fang, Chem. Res. Chin. Univ., 2006, 22, 129-133.

29 X. Fang, Y. Zhan, J. Yang and D. Yu, J. Mol. Catal. B: Enzym., 2014, 104, 1-7.

30 X. Zhang, L. Shi, X. Li, Q. Sheng, L. Yao, D. Shen, Z. R. Lü, H. M. Zhou, Y. D. Park, J. Lee and Q. Zhang, J. Biosci. Bioeng., 2014, 117, 696-705.

31 J. Yang, Y. Shen, Y. Hong, F. Jin, S. Zhao, M. Wang, X. Shi and X. Fang, J. Ethnopharmacol., 2008, 117, 285-289.

32 G. Ardif, P. Reboul, J. P. Pelletier and J. Martel-Pelletier, Mod. Rheumatol., 2004, 14, 197-204.
33 K. Hashizume, J. Reprod. Dev., 2007, 53, 1-11.

34 M. A. Weaver, Clin. Exp. Metastasis, 2006, 23, 97-105.

$35 \mathrm{~T}$. Weihua, Inhibition study of Matrix Metalloproteinase by inhibitor in Herb Korean Monkshood Root and metal ions inhibitor, MPhil, Northwest University, Xi'An, 2009.

36 T. J. Smeets, M. C. Kraan, S. Galjaard, P. P. Youssef, M. D. Smith and P. P. Tak, Ann. Rheum. Dis., 2001, 60, 561565.

37 Y. S. Kim and T. H. Joh, Biomol. Ther., 2012, 20, 133-143.

38 Y. Itoh, IUBMB Life, 2006, 58, 589-596.

39 V. Pelmenschikov and P. E. M. Siegbahn, Inorg. Chem., 2002, 41, 5659-5666.

40 E. Decaneto, S. Suladze, C. Rosin, M. Havenith, W. Lubitz and R. Winter, Biophys. J., 2015, 109, 2371-2381.

41 F. X. Gomis-Rüth, J. Biol. Chem., 2009, 23, 15353-15357.

42 S. Deslandes, C. Galaup, R. Poole, B. Mestre-Voegtlé, S. Soldevila, N. Leygue, H. Bazin, L. Lamarque and C. Picard, Org. Biomol. Chem., 2012, 10(42), 8509-8523.

43 S. Linse, B. Jönsson and W. J. Chazin, Proc. Natl. Acad. Sci. U. S. A., 1995, 92(11), 4748-4752.

44 L. G. Rodriguez, X. Wu and J. L. Guan, Methods Mol. Biol., 2005, 294, 23-29. 